\title{
Ortopedi ve Travmatoloji dalında iç rekabet
}

\section{Competition in orthopedics and traumatology}

\author{
Halit Pınar \\ Dokuz Eylül Üniversitesi Tıp Fakültesi, Ortopedi ve Travmatoloji Anabilim Dalı, İzmir
}

\begin{abstract}
Rekabet temel toplumsal etkileşim biçimlerinden birisidir. Aynı amacı güden kimseler ve kuruluşlar arasındaki çekişme, yarışma olarak tanımlanır. Bu, daha iyiye ulaşmak için üstün olma mücadelesidir. Rekabet üretken olabildiği gibi yıkıcı da olabilir; yani, "olumlu" ve "olumsuz" rekabetten söz edilebilir. Ortopedi ve Travmatolojide de -her tıp dalında olduğu gibirekabetin genel koşullarının yanında özel koşulları da mevcuttur. Aslında işbirliği ve dayanışma, egemen olması gereken daha değerli iki davranış biçimidir. Ortopedi ve Travmatolojide rekabetin nedensel olarak başlıca üç alanda olduğu görülür: mesleki, akademik ve ekonomik. Bunlardan ilk ikisi belli oranda üçüncüsü yani ekonomik rekabet ile ilişkilendirilebilir. Mesleki ve ekonomik rekabette performans sisteminin ve özel kurumların kendine özgü koşullarının negatif etkileri yadsınamaz. Akademik rekabetin olumlu etkileri yanında, haksız rekabet koşulları ve yayın etiği ihlalleri gibi olumsuzlukları da irdelenmelidir. Hekim-hekim, hekim-hasta, hekim-endüstri arasındaki etik olmayan ilişkiler, tanıtım kuralları ihlalleri, endikasyon hataları gibi olumsuzluklar, ekonomik rekabetin aşıması gereken ciddi sorunları olarak önümüzde durmaktadır.
\end{abstract}

Anahtar sözcükler: ortopedi; travmatoloji; rekabet
Competition is one of the many ways of social interaction. The struggle among people and organizations having the same purpose is defined as competition. It is a struggle to reach a better outcome. It may have a productive effect, but at times it may be disruptive; so there are two types: positive and negative competition. Indeed, solidarity and collaboration should be the dominant behaviours instead of negative competition. As in every medical branch, general conditions and unique individual factors play role in orthopedics and traumatology. In general, competition may be divided into three areas: professional, academic and economic. To a certain degree, the first two may be related to the last one. The negative role of official regulations and unique conditions of private health organizations in professional and economic competition should be emphasized. Besides positive effects of academic competition, unfair competitive conditions and infringement of publishing ethics are well-known problems to be solved. Unethical interphysician, physician-patient, physician-industry relations, overtreatment, and violation of advertisement regulations are the serious problems ahead of us.

Key words: orthopedics; traumatology; competition
$\mathbf{R}$ ekabetin Türk Dil Kurumu (TDK) sözlüğündeki karşılığı şöyle: "aynı amacı güden kimseler arasındaki çekişme, yarışma, yarış". Sosyoloji biliminde ise, aynı işi yapan kimseler ya da kuruluşlar arasındaki daha iyiye ulaşma yarışması, bu uğurda sürdürülen üstün olma mücadelesi diye tanımlanır.

Toplum yaşamında bireyler veya gruplar farklı şekillerde karşı karşıya gelirler. Sosyolojide bu karşılaşma biçimleri "toplumsal etkileşim" olarak adlandırılır. Sosyolojide, tüm toplumlarda geçerli olan ve bu nedenle evrensel süreçler olarak kabul edilen temel toplumsal etkileşim biçimlerinden birisidir rekabet. Diğer etkileşim biçimleri ise işbirliği, mübadele, çatışma, bas$\mathrm{kı}$, uyum, uyarlama ve benzeştirmedir.
Rekabet yaşamın bir gerçeğidir; üretken olabildiği gibi yıkıcı da olabilir. O halde, "olumlu" ve "olumsuz" rekabetten söz edilebilir.

Aslında "rekabet" sözcügüune olumlu anlam yüklemeliyiz. Olumlu rekabette kişi tamamen kendi yetenek ve değerlerine odaklanır, başkalarının ne yaptığı ile ilgilenmez; başkalarının kaybetmesi ile değil, kendisinin kazanması ile ilgilidir; kazanmak için uygun olmayan yöntemler kullanmak ve başkalarına kötülük etmek dâhil her yolu denemek gibi bir düşünce içerisinde olmaz; kazanmak gibi kaybetmenin de normal karşılanması gerektiğinin bilincindedir. Kaybetmek onu kötü ve değersiz bir kişi yapmayacaktır. Sonuç ne olursa olsun, tüm taraflar ilerleme kaydetmiş olacaktır.

- İletişim adresi: Prof. Dr. Halit Pınar, Dokuz Eylül Üniversitesi Tıp Fakültesi, Balçova, İzmir

Tel: 0532 - 4165546 e-posta: halit.pinar@deu.edu.tr

- Geliș tarihi: 9 Ekim 2019 Kabul tarihi: 11 Kasım 2019 
Normalde yenilenme ve gelişme getirmesi beklenen rekabet bazen olumsuzluklar doğurabilir; aşırı hırs ve bencillik gibi bireysel özelliklerin güdümünde ilişkileri olumsuz etkiyebilir, hattâ çatışmaya neden olur. Burada, diğer kişi veya kişilerin adeta yok olması pahasına bir kazanma arzusu söz konusudur. Neye mal olursa olsun ben kazanmalıyım şeklindeki bir anlayışın o kişiye iç huzurunu getirmeyeceği açıktır. "Hırçın” rekabet olarak da tanımlayabileceğimiz bu davranış biçimi, yüksek ego, kibir ve hasetlik gibi kavramlarla da el ele gider. Bir kurum veya topluluk içinde düşünüldügünde, olumlu rekabet o yapıyı yüceltirken, olumsuz rekabet topyekûn bir gerilemeye neden olabilecektir. Olumsuz (yıkıcı) rekabet, birisinin başarısızlığı ile mutlu, başarısıyla da mutsuz olma ile karakterizedir.

İnsanlık tarihinde geriye doğru gittikçe rekabet yıkıcı bir durum gibi görünürken, modern toplum kültüründe rekabetin bir çözüm ve motivasyon aracı olarak sunulmaya başlandığını görmekteyiz. Ancak, durum tam olarak da böyle midir, tartışılır.

Ortopedi ve Travmatoloji dalında iç rekabetten söz edersek, öncelikle rekabetin genel koşullarının elbette burada da geçerli olduğunu belirtmeliyiz. Doğallıkla, sağlık bilimi olmanın getirdiği özel koşullar da etkilidir. Sağlıkla ilgili bir kurumda, herhangi bir kurumsal yapının iç dinamiklerinden daha fazlası vardır; hekimlerin meslektaşları, hastaları ve endüstri ile ilişkileri ve etkileşimleri söz konusudur. Dolayısıyla, farklı kesimlerden bireylerin varlığının rekabet sıklığını artırıı, alanlarını ve tiplerini çeşitlendirici etki yapması beklenmelidir. Rekabeti etkileyen başlıca faktörler içsel (bireysel) ve dışsal (kurumsal ve kurallara bağlı özellikler) olarak ikiye ayrılabilir. Dışsal faktörler ile kastedilen kurum içi dengeler ve çalışma koşullarımızı düzenleyen kanun ve yönetmeliklerdir.

\section{ORTOPEDI VE TRAVMATOLOJIDE REKABET}

Biz hekimlerin başta gelen görevi, hastaya en iyi hizmeti sunmaktır. Bu öncelikli amacımıza ulaşmak için sağlık bilimlerini ilgilendiren tüm dallarda olduğu gibi Ortopedi ve Travmatolojide de rekabetten daha değerli olan iki davranış biçimi, işbirliği ve dayanışma olmalıdır. Yine de rekabet, yaşamın ve toplumsal etkileşimin bir gerçeği olarak önümüzde durmaktadır. Her meslek grubu veya popülasyonun kendi iç dinamikleri ve özelliklerinden kaynaklanan farklı rekabet şekilleri vardır. Örneğin; ticaret yaşamında rekabet hekimlikte olandan çok farklı şekillerde ortaya çıkabilir.

Ortopedi ve Travmatolojide rekabetin nedensel olarak başlıca üç alanda olduğu görülür: mesleki, akademik, ve ekonomik. Hemen -ayrıntıya girmeden- belirtmek isterim ki, aslında ilk ikisi belli oranda ekonomik rekabet ile ilişkilendirilebilir.

\section{Mesleki Rekabet}

Ortopedi ve Travmatoloji uzmanları olarak, öncelikli işimiz şüphesiz insan sağlığıdır. Hastalara daha iyi hizmet verebilmek her hekimin öncelikli hedefi olmalıdır. Bu da dalın uzmanları arasında ön plana çıkma güdüsü ile paraleldir; burada bir rekabetten söz edilebilir. Genel Ortopedi ve Travmatoloji pratiği için bu rekabetin olumsuz bir etkileşim olması pek beklenmeyebilir. Uzman kişi sadece kendisine odaklı olmalı ve diğer meslektaşlarının durumu ile ilgilenmemelidir. Ne var ki, dallanmanın uzmanlar arasında tercih edilir olma güdüsünü artırdığını ileri sürmek pek de yanlış olmayacaktır. Özellikle dar iş çevresinde (il, ilçe, bölge) hastalar tarafından olduğu kadar özel sağlık kuruluşları tarafından da tercih edilir olma çabası, rekabetin olumsuz yönünü de bazen ortaya çıkarabilmektedir. Özel sağlık kuruluşundan söz etmişken; burada "daha iyi" olmak, uzmanın konumunu sağlamlaştırıcı etki yapacaktır. Resmi sağlık kuruluşlarında da -performansa dayalı hizmet sisteminde"daha iyi" olmak daha fazla hasta anlamına gelip, bu da daha fazla puan getirecektir.

Aslında sadece daha iyi hekim olma ve hastalara daha iyi hizmet verme hedefine yönelik olumlu (tatIı) rekabet, günümüz sağlık sisteminde, iş güvencesi sağlama ve daha fazla puan toplama adına daha hırçın bir hal alabilmektedir. Hırçın rekabet dememizin nedeni, kişinin sadece kendi gelişimine odaklı olmayıp, diğer hekimlere odaklandığı bir yarış içine girebilmesidir. Dayanışmacı bir tavır, yerini kolayca ekonomik çıkarların güdülediği farklı bir etkileşime bırakabilir.

\section{Akademik Rekabet}

Her dalda olduğu gibi bizim dalımızda da, bazı uzmanlar mesleklerini akademik ortamda yürütmeyi tercih etmektedirler. Bu durumda, meslek pratiğine ek olarak, araştırma yapmak ve ders vermek gibi görevleri de üstlenirler. Her üç görev de birlikte olarak üniversite çatısı altında yürütülür.

Akademik yaşam için, ilerlemenin, daha iyiye ulaşmanın ana unsurudur demek yanlış olmaz. Burada, esas hedefin insan sağlığı olduğunu bir kez daha anımsatmak isterim. Akademisyenliği seçen bireylerin bu hedefe ulaşmak için araştırmalar ve bilimsel çalışmalar yapmaları beklenir. Aslında bilimsel rekabetin daha iyiye ulaşmada olumlu etkisinden söz etmek gerekir. Önemli oranda doğru olmakla birlikte, bunun bazı olumsuzlukları da beraberinde getirdiğine tanıklık etmekteyiz.

Akademik yaşama başlamanın ve bu yolda ilerlemenin bazı kriterler olmaksızın gerçekleştirilmesi 
düşünülemez. Bu durumun da yarışmacı bir ortamı beraberinde getirmesi doğaldır. Bu noktada herkesin çevresi yerine kendisine ve kendisini öne taşıyacak çalışmalara odaklanması gerekir; sonunda başarı gelecektir. Kişinin kendisine avantaj sağlamak için kendi bilimsel çalışmalarına odaklanmak ve çalışmak yerine başka yolları da devreye sokma çabası, bilim ve yayın etiğine aykırılıkları ortaya çıkarabilmektedir.

Yurtiçi ve yurtdışında örneklerini gördüğümüz üzere, yayın etiği ihlalleri pek çok farklı şekillerde karşımıza çıkabilmektedir; konu ayrı bir yazının başlığı olmayı hak edecek kadar geniştir. Ülkemizde bu tip olumsuz rekabeti en çok doçentlik sınavları için hazırlanan dosyalarda görmekteyiz.

Rekabette olumsuz koşulların en az görüldüğü alanın akademik rekabet olması beklenir, çünkü en net değerlendirme kriterleri akademik yükseltmelerde mevcuttur. Ancak, objektif kriterlerin varlığına rağmen değerlendiricilerin subjektif davranması haksız rekabetin önemli ve azımsanmayan sıklıkta görülen bir nedeni olmaktadır.

Haksız akademik rekabet koşullarını ayrıca kadro ilanlarında da görebilmekteyiz. Olağan koşullar altında ilanlardaki özel tanımlamalarla olumlu ve geliştirici rekabet şartları bazen daha baştan ortadan kaldırılmış olabilmektedir. Kişileri idari makamlar nezdinde bireysel kadro arayışlarına iten norm kadro uygulamasından da -olağan koşulları ortadan kaldırması nedeniyle- olumsuz bir faktör olarak burada söz etmek isterim.

Akademik rekabette haksızlığa uğramış bireylerin varlığının o dal için mutsuzluk nedeni olması gerekir. Herkes bu konuda duyarlı olup, bu durumu en aza indirmek için üzerine düşeni yapmalıdır. Uygun rekabet koşullarının sağlanamamasının, yaralayıcı olma yanın$\mathrm{da}$, o dalın ileriye gitmesinin önünde önemli bir engel olduğu da bilinmelidir. Bu olumsuzluğun, sonunda hastalarımızın sağlığına da yansıması beklenir.

\section{Ekonomik Rekabet}

Mesleki ve akademik rekabette ulaşılmak istenen hedefte, herkes için değişen oranlarda ekonomik getirinin de bulunduğu saptamasını yapmak pek de yanlış olmasa gerektir. Yani, diğer iki rekabetin içinde ekonomik rekabetin de bulunduğunu vurgulamak gerçekçi olacaktır. Doğru olan, mesleki ve akademik rekabetin, ekonomik rekabetin araçları olmamasıdır. Her birey mesleğinde yetkin ve donanımlı olmayı hedefleyerek hastasına daha yararlı olmak ister. Daldaki uzmanlar içinden bir grup ek olarak eğitim vererek ve bilimsel çaIışmalar da yaparak alanına katkı vermeyi düşünebilir ve bir rekabet içine girebilir. Burada söz edilen olumlu rekabettir. Bunun sonucunda, ekonomik kazanımlar ekonomik bir rekabetin içinde olmaksızın zaten elde edilmiş olur.

Ekonomik avantaj sağlama isteği kişiyi doğrudan bir rekabetin içine çekiyorsa, bu durumda olumsuz tavırlar ortaya çıkabilmektedir. Burada ekonomik getiri öncelikli hedef olmuştur; hastalara yararlı olmak, araştırma yapmak gibi olumlu unsurlar söz konusu değildir. Mesleki değerler ve bilimsel özellikler geri plana itilince, "hırçın" bir ekonomik rekabetin çeşitli unsurları belirginleşir.

Burada, sağlık sisteminin rolünü daha en başta net olarak ortaya koymak gerekir. Performansa dayalı sistemin hekimlik uygulamalarına olumsuz etkileri çeşitli platformlarda yeterince irdelenmiş olup bu yazıda ayrıntılı olarak ele alınmayacaktır. Resmi kurumlarda hekimlik uygulamalarında puan toplama kaygısının ne yazık ki gereksiz ameliyatlara yol açabildiğini görmekteyiz. Bazı ameliyatlarda endikasyon geniş tutulurken, bazıları da yapılmak istenmemektedir. Bazı özel hastanelerde ise hekim, üstü kapalı da olsa, daha fazla ameliyat yapması yönünde baskı hissedebilmektedir.

Günümüzde sosyal medyanın yaygınlaşmasıyla birlikte, tanıtım kuralları ihlalleri ekonomik rekabetin dikkat çekici (olumsuz) araçları haline gelmiştir. Hekimin internet ortamında kendisini tanıtması doğaldır; hastalar da giderek daha sıklıkta internette hekim araştırması yapmaktadır. Hekimin kendisi ile ilgili bilgileri abartması, değerini artırmak amacıyla gerçek dışı beyanlarda bulunması en sık karşılaştığımız durumlardır. Kişinin bir etkinlikte eğitici olarak görev aldığını duyuruş şekli bile ekonomik getirinin ana beklenti olduğuna dair ipucu verebilir.

Son yıllarda dalımızda önemli bir gelir kaynağı olarak öne çıkan rejeneratif tıp ve alternatif tıp uygulamaları üzerine internet ortamında yer alan bilimsellikten uzak bilgiler dikkat çekicidir, üzücüdür. Aslında tanıtım ilke ve kuralları Türk Tabipleri Birliği (TTB) tarafından net bir şekilde ortaya konmuştur. ${ }^{[1]}$

Doğrudan bir rekabet tavrı olmasa da, ekonomik getiri söz konusu olduğunda, zaman zaman örneklerine rastladığımı iki olumsuzluğa da konu bütünlüğü için yer vermekte yarar görmekteyim. Bunlardan birisi hekimin resmi kurum çatısı altında hasta ile doğrudan ekonomik ilişki içine girmesidir. Bunun, mesleğimiz için en alçaltıcı davranışlardan birisi olduğunu düşünmekteyim. Olumsuz rekabet koşulları içinde değerlendirebileceğimiz bir diğer durum da, hekimin endüstri ile doğrudan ekonomik ilişki içinde olmasıdır. Bu durumun hekimin endikasyonlarını etkilemesi olasılığına dikkat çekmek isterim. 


\section{NE YAPMALI?}

Rekabetin geliştirici ve verim artırıcı yönde kullanılması, o kişiye olduğu kadar ülkemizin Ortopedi ve Travmatoloji pratiği, dolayısıyla hastalarımız için en iyi sonuçları verecektir. Olumsuz rekabeti geri plana itmek için hem bireysel hem de çevresel faktörlerin aşılması gerekir. Bireylerin sadece kendilerine odaklanarak mesleklerinde iyiye ulaşmaları, zaten -istedikleri takdirde- akademik hedeflerine ulaşmalarını da mümkün kılacaktır. Olumsuz rekabet koşullarını tetikleyen çevresel koşullarla (kanunlar, kararnameler, vb.) mücadele hepimizin ortak görevi olmalıdır. Ekonomik hedeflere olumsuz rekabet koşullarında ulaşmaya çalışmak o kişi için pek çok olumsuzluğu beraberinde getirecektir. Önce iyi bir birey, sonra iyi bir hekim olmakla -çevresel koşulların da izin vermesi ile- diğer hedeflere zaten ulaşılacaktır.

\section{KAYNAKLAR}

1. Ersoy V, Güler M, Giritlioğlu H Sağlık Hizmeti Sunumunda Reklam ve Tanıtım. Türk Tabipleri Birliği Yayınları. 1. Baskı, Ankara: Mayıs 2008. ss.10-2. 